\title{
Paths for Future Research on Nation-building: Causal Mechanisms and Theoretical Antecedents
}

Nation Building: Why Some Countries Come Together While Others Fall Apart. By

Andreas Wimmer. Princeton: Princeton University Press, 2018. 376p. \$39.95 cloth, \$27.95 paper.

Andreas Wimmer's book makes several major contributions to the study of not only nationalism but also state formation. Theoretically, the book both provides novel arguments based on voluntary associations as well as linguistic characteristics and takes the additional step of exploring the antecedents of these factors. Empirically, it uses an impressive combination of qualitative and quantitative methods as well as macro and micro analyses to assess these arguments. In what follows, I briefly summarize these important contributions and highlight the aspects that can be further specified and tested by future research.

The main argument of the book introduces three mechanisms that contribute to successful nation-building. The first goes through the existence of early and even spread of voluntary associations, the second focuses on linguistic homogeneity among the elite of potentially separate identity groups, and the last one is the extent to which public goods provision treats groups equally. These mechanisms open the door for a theoretical question that can be further addressed in future research. What exactly is the relationship between the three mechanisms? Do "early and even voluntary associations" and "linguistic homogeneity among the elite" constitute two separate paths that result in equal provision of public goods and, eventually, successful nation-building? Or is the provision of public goods a standalone mechanism? The discussion from case comparisons including Russia and China (on linguistic homogeneity) or Belgium and Switzerland (on the distribution of voluntary associations) implies that these factors lead to equal representation of elites from different backgrounds. Would it be possible to observe equal representation of elites with different backgrounds without proper provision of public goods? This type of situation might arise if the multicultural elite collude on some other characteristic such as social class that separates them from the rank and file of their respective groups. These elites then could neglect the provision of social safety to the masses, leading to a situation in which there is equal but very low levels of public goods provision. Would we then count this type of situation as successful nation-building?

Second, to what extent is there an element of path dependence in the argument? Wimmer's theory focuses on long-term processes of political development. Furthermore, the arguments on voluntary associations highlight the role of both even and early spread of such associations. Therefore, one theoretically significant question that future research can explore is what happens if there is delay in the emergence of voluntary associations but then due to new circumstances a relatively even spread of voluntary associations occurs? Would we then expect the divisions or practices of exclusion that emerge in the earlier period to disappear over time? Or would the divisive patterns prove sticky despite the change in the nature of voluntary associations? The historical element in Wimmer's arguments also leads to another potential avenue for empirical research. Specifically, it would be useful for future studies to use indicators for voluntary associations that reach earlier than the data from 1970 that the book 
uses. Short of developing original data, one possibility would be some of the indicators that exist in the new V-dem data set that capture civil society organizations (Coppedge et al. 2019).

Third, a really creative section of Wimmer's book is the argument on the sound-word based nature of Chinese languages and how this aspect of Chinese languages allowed the educated elite to communicate with each other despite mutually unintelligible spoken languages. Wimmer argues that the resulting elite homogenization and relatively equal access to power at the elite level contributed to successful nation formation in China compared to the Russian Empire. Wimmer's argument on the nature of written language in fact offers testable implications for what types of groups should be more easily incorporated into the nation than others. For example, it suggests that the Ukrainians, who spoke a language mutually intelligible with Russian and used the Cyrillic alphabet, should have been relatively easy to incorporate. Wimmer's study actually finds Ukrainian nationalists to be quite popular. Yet, it is possible (and historical evidence suggests) that compared to other groups (such as the Poles), the Ukrainian national movement was indeed weaker (Miller 2003, 252, 253). The ultimate failure of the Russian Empire to form a coherent nation state out of groups such as the Ukrainians might be because the idea of minority nationalism became popular and wide-spread in early $20^{\text {th }}$ century Europe in a way that it did not in East Asia.

A fourth aspect of the argument that future research can elaborate on relates to the conditions under which the elite can successfully disseminate their collective identity to the rest of the population. When studying the Jewish elite in the Bund, Wimmer discusses how the Russianspeaking elite experienced difficulties disseminating their ideas at the grassroots level and eventually switched to Yiddish to be able to reach the non-Russian-speaking Jews. This argument is quite convincing on its own. However, it also raises the question of why the Chinese literate elite did not have the same problem reaching the regional populations who often spoke mutually unintelligible languages and were largely illiterate.

A fifth aspect of the argument that raises questions relates to the conceptual definition of successful nation formation. Wimmer argues that oppression and physically harming populations counts as failure. On a normative basis, it is hard to disagree with this statement. Nevertheless, this approach leaves several conceptual issues unattended. Historically, there are countries that hold together while they oppress and physically harm whole groups: China, which Wimmer treats as a case of success (at least compared to Russia), would potentially count among these cases. One way in which Wimmer deals with China's treatment of Tibetans and the Xinjiang Province is by arguing that these cases are internal colonies. And yet the very formation of internal colonies suggests the existence of highly exclusionary and oppressive institutions on the territory of the state, which after all is part of Wimmer's main outcome variable. Furthermore, one should also recall that the relevant scholarship on the topic defines the Russian invasions into non-Russian territories such as Central Asia and the Caucasus as internal colonization (Khodarkovsky 2002). An additional area of conceptual ambiguity relates to the role of assimilation. Eugen Weber's classical work teaches us that even in states that were early movers in nation state formation such as France, there existed significant pressure (one could say oppression) to force children using regional vernaculars or other languages such as Breton to adopt standard French. Is France a case of success or failure in terms of nationbuilding? More abstractly, if a state used oppressive or quasi-oppressive assimilation in the past and achieved its goal, does this count as success or failure? These questions suggest that it would be useful for future research to refine categories of nation-building success based on 
type (physical violence versus disciplinary/bureaucratic mechanisms), extent (percentage of population influenced), and geographical reach of oppression (percentage of territory covered).

Finally, one of the impressive aspects of the book is its willingness to go deeper into the historical antecedents of linguistic homogeneity. The main antecedent condition that the book identifies is prior state centralization, which primarily shapes linguistic homogeneity and state capacity to provide public goods. On the topic of antecedents, the most interesting question that the book leaves out is why some contexts (such as Switzerland) develop early and even distribution of voluntary associations whereas others (such as Belgium) do not. This question is especially critical as the argument on voluntary associations is also the most original part of the book's theory. One potential possibility, which the qualitative empirical section on Switzerland also points to, is economic inequality prior to industrialization. Lower levels of land or regional inequality might encourage and enable early development of these organizations by generating common interests and by making it less attractive for the more wealthy and powerful to repress such organizations. Another possibility is the historical experience of foreign rule and occupation. As Wimmer shows, despite not entering the war, WWI stoked some ethnic tensions in Switzerland. What would have happened to voluntary associations, particularly of cross-cutting variety, if Germany had occupied Switzerland during WWI and WWII and repressed French speakers while elevating German speakers? ${ }^{1}$ After all, Belgium experienced occupation in both instances. Even in the earlier periods, Belgium had a different experience. During the Napoleonic wars, it experienced longer and deeper French involvement and, unlike Switzerland, it was historically under Habsburg rule. Economic inequality and foreign rule are only two potential explanations for voluntary associations; future research can identify others. The main point here is that, given Wimmer's work, the antecedents for these organizations emerges as a significant question for scholars of nationalism.

H. Zeynep Bulutgil, University College London z.bulutgil@ucl.ac.uk

\section{References}

Bulutgil, Zeynep H. 2016. The Roots of Ethnic Cleansing in Europe. Cambridge

\section{University Press.}

Coppedge, Michael, John Gerring, Carl Henrik Knutsen, Staffan I. Lindberg, Jan Teorell, David Altman, Michael Bernhard, M. Steven Fish, Adam Glynn, Allen Hicken, Anna Lührmann, Kyle L. Marquardt, Kelly McMann, Pamela Paxton, Daniel Pemstein, Brigitte Seim, Rachel Sigman, Svend-Erik Skaaning, Jeffrey Staton, Steven Wilson, Agnes Cornell, Lisa Gastaldi, Haakon Gjerløw, Nina Ilchenko, Joshua Krusell, Laura Maxwell, Valeriya Mechkova, Juraj Medzihorsky, Josefine Pernes, Johannes von Römer, Natalia Stepanova, Aksel Sundström, Eitan Tzelgov, Yi-ting Wang, Tore Wig, and Daniel Ziblatt. 2019. "V-Dem [Country-Year/Country-Date] Dataset v9, ” Varieties of Democracy (V-Dem) Project. (Accessed 1/2/ 2020) https://doi.org/10.23696/vdemcy19.

\footnotetext{
${ }^{1}$ For example, on how occupations might influence nationalist radicalization within ethnic groups, see Bulutgil (2016).
} 
Khodarkovsky, M. 2002. Russia's Steppe Frontier: The Making of a Colonial Empire, 15001800. Indiana University Press.

Miller, Alexei. 2003. Ukrainian Question: Russian Empire and Nationalism in the 19th Century. Central European University Press,

Weber, Eugen. 1976. Peasants into Frenchmen: The Modernization of Rural France. Stanford University Press. 